\title{
Immobilization of Mucor racemosus NRRL 3631 lipase with different polymer carriers produced by radiation polymerization
}

\author{
Mostafa, H. and El-Hadi, A. A.* \\ National Research Centre, Dokki, 12622 Giza, Egypt. \\ E-mail: abeerelhag@yahoo.com
}

Received 29 July 2009; received in revised form 19 November 2009; accepted 30 November 2009

\begin{abstract}
Lipase was partially purified from the culture supernatant of Mucor racemosus NRRL 3631. In an attempt to increase the enzyme stability, the enzyme was immobilized on poly (vinyl alcohol) PVA, radiation cross liked poly (vinyl alcohol/ vinyl pyrrolidone) PVA / PVP and poly (vinyl alcohol/ hydroxyethylmethacrylate) PVA/ HEMA hydrogels. The maximum immobilization yield (31.74\%) was obtained using PVA/ HEMA copolymer. The effect of the immobilization parameters on the enzyme such as the hydrogel composition, irradiation dose and the immobilization technique was performed. An optimum radiation dose of $15 \mathrm{kGy}$ and hydrogel composition of $10 \%$ PVA/ HEMA (9.6: $0.4 \mathrm{v} / \mathrm{v}$ ) increased the immobilization yield to $60.3 \%$. Diffusion phenomena can be markedly increased the enzyme immobilization on the surface of the hydrogel. In this case the retained activity was approximately $81.5 \%$ of that of the free enzyme. The profiles of immobilized enzyme activities at various $\mathrm{pH}$ values (4-9) and temperatures $\left(30-80{ }^{\circ} \mathrm{C}\right)$ showed an overall higher stability for the immobilized enzyme than that for the free one. The half life values of the immobilized and free enzymes at $60{ }^{\circ} \mathrm{C}$ were $3.3 \mathrm{~h}$ and $1.73 \mathrm{~h}$, respectively. The immobilized enzyme retained $69.2 \%$ of its initial activity after three cycles.
\end{abstract}

Keywords: lipase, Mucor racemosus, polymer carriers, radiation polymerization

\section{INTRODUCTION}

During the last decade, lipase has become of great interest to the chemical and pharmaceutical industries owing to their usefulness in both hydrolytic and synthetic reactions. With recent advances in enzyme technology, many approaches have been made to employ the enzyme on a laboratory scale. Some industrial processes have been elaborated (Norin et al., 1988; Kilbanov, 1990, Inagaki et al., 1991; Roberts and Turner, 1992; Bagi et al., 1997).

Immobilized lipases offer economic incentives of enhanced thermal and chemical stability, ease of handling easy recovery and reuse relative to non- immobilized forms (Malcata et al., 1990; Kanwar et al., 2004, Pahujani et al., 2008; Vaidya and Singhal, 2008). There are many factors which influence the performance of an immobilized enzyme preparation. Some of the most important factors are the choice of a carrier and the selection of an immobilization strategy (Cho and Rhee, 1993).

The choice of the three dimensional network matrix is very important for the good performance of an immobilized enzyme system. It is then desirable that the enzyme carrier possess large surface area, high permeability, hydrophilic character, chemical, mechanical and thermal stability. There are several methods to minimize hindrance of enzyme diffusion to the hydrophilic carriers, including the selection of monomers and crosslinking agents which can modify both the porous structure and pore size of the gel and low-molecular weight polymers (Fokina et al., 1995; Lozinsky et al., 1997; Pizarro et al., 1997; Giuliano et al., 2003).

There are several techniques of immobilization including chemical and irradiation techniques. Hydrogel which is produced by irradiation technique has several advantages including the speed of processing, simplicity in synthesis, the uniform of attachment of the insolubilized reagent on the polymer-matrix, loss of its ability to dissolve in its customary solvents in addition to the sharp growth in its mechanical properties (Higa et al., 1986; Abd El-Hadi, 2003). Poly vinyl alcoholhydrogel, is an example of polymer produced by $\mathrm{Y}$-radiation polymerization that has showed (I): remarkable stability over a prolonged period in acidic, alkaline and saline media (II): PVA is a biologically compatible, non toxic, readily available and low cost polymer iii: PVA are highly resistant to biological degradation as well as being insensitive to a composition of working media i.e, the carriers (in contrast to alginate or carrageenan matrices) do not undergo undesirable weaking as a result of the presence of certain solutes in the media.( Lozinsky et al., 1997).

The present study demonstrated the immobilization of Mucor racemosus lipase on different polymer carriers, poly (vinyl alcohol grafted with 2-hydroxyethylmethacrylate) (PVAg-2HEMA) \& poly (vinyl alcohol grafted with poly vinyl pyrrolidone) (PVA/ PVP). The main objectives of this work were to evaluate the effect of the immobilization variables (the effect of polymer composition, total 
absorbed $\mathrm{y}$-irradiation dose and different techniques of immobilization) to the immobilization process and to obtain the optimum conditions for immobilized lipase finally, the properties of the immobilized enzymes such as $\mathrm{pH}$, thermal stability and kinetic behavior and reusability were studied.

To the best of our knowledge, lipase has been already immobilized by physical adsorption on CMsephadex C-50, alumina, silica gel and cellulose. (Brinbaum, 1994). But there are no studies in the literatures reporting the immobilization of lipase into radiation cross linked poly (PVA/ HEMA) hydrogel.

\section{MATERIALS AND METHODS}

\section{Chemicals}

Glucose, potassium chloride, potassium dihydrogen phosphate, magnesium sulphate, disodium hydrogen phosphate and Arabic gum were products from BDH chemical LTO, POK, England. Peptone from animal protein, sodium dihydrogen phosphate and acetone were products of Fluka company, Swizerland. Also Poly (vinyl alcohol) PVA (14000 m.w.), Hydroxyethylmethacrylate (HEMA) and poly (vinyl pyrrolidone) PVP (13.000.000 m.w $\mathrm{K}_{85-95}$ ) were supplied by Arcos Organic Co, Belgium.

\section{Microorganism, medium and growth conditions}

Mucor racemosus NRRL 3631 was maintained on potatodextrose agar slants of PDA formula. The microorganism was grown in $250 \mathrm{~mL}$ Erlenmeyer flasks containing 100 $\mathrm{mL}$ of medium. The medium was inoculated with $4 \mathrm{~mL}$ of spore suspension and the flasks were incubated for $72 \mathrm{~h}$ in an orbital shaker operating at $200 \mathrm{rpm}$ at $30^{\circ} \mathrm{C}$.

For lipase production, the composition of the basal medium with an initial $\mathrm{pH}$ value of $6.5(\mathrm{~g} \% \mathrm{w} / \mathrm{v})$, glucose, 1 ; olive oil, 1; peptone, $30 ; \mathrm{KH}_{2} \mathrm{PO}_{4}, 0.2 ; \mathrm{KCl}, 0.05$ $\mathrm{MgSO}_{4} .7 \mathrm{H}_{2} \mathrm{O}, 0.05 \%$ (Akhtar et al., 1980). The medium was heat sterilized $\left(121^{\circ} \mathrm{C}\right.$ for $\left.15 \mathrm{~min}\right)$.

\section{Standard method for enzyme activity assay}

Lipase assay was performed with olive oil emulsion by the procedure of (Starr, 1941). Olive oil emulsion was prepared as follows: $10 \mathrm{~mL}$ olive oil and $90 \mathrm{~mL}$ of $10 \%$ Arabic gum were emulsified by a homogenizer for $6 \mathrm{~min}$. at $20.000 \mathrm{rev}$. / $\mathrm{min}$. The reaction mixture composed of 3 $\mathrm{mL}$ olive oil emulsion, $1 \mathrm{~mL} 0.2 \mathrm{M}$ Tris-buffer ( $\mathrm{pH} 7.5), 2.5$ $\mathrm{mL}$ dist. Water and $1 \mathrm{~mL}$ enzyme solution were incubated at $37^{\circ} \mathrm{C}$ for $2 \mathrm{~h}$ with shaking. The emulsion was destroyed by addition of $10 \mathrm{~mL}$ acetone $(95 \% \mathrm{v} / \mathrm{v})$ immediately after incubation, and liberated free fatty acids were titrated with $0.05 \mathrm{~N} \mathrm{NaOH}$. One unit of lipase was refined as the amount of enzyme liberated $1 \mu \mathrm{mol}$ of fatty acids.

\section{Analytical Procedures}

\section{Protein analysis}

Protein measurements were carried out by the method of Lowry et al. (1951) using bovine serum albumin as standard. The amount of bound protein was determined indirectly from the difference between the amount of protein present in the filtrate and washing solutions after immobilization.

\section{Partial purification of Mucor racemosus lipase by ammonium sulphate}

To $900 \mathrm{~mL}$ of culture supernatant, ammonium sulphate was added (60\% saturation) at $4^{\circ} \mathrm{C}$. The precipitate was collected by centrifugation at $12000 \times g$ at $4{ }^{\circ} \mathrm{C}$ for $20 \mathrm{~min}$ and dissolved in a constant amount of distilled water. The lipase activity and protein concentration were determined. (Abbas et al., 2002).

\section{Biochemical characterization of Mucor racemosus immobilized lipase}

The thermostability of immobilized enzyme was studied by incubating the biocatalyst at $30-80{ }^{\circ} \mathrm{C}$ for 15,30 and 60 min in a water bath. Likewise to determine stability at varying $\mathrm{pH}$, the immobilized enzyme was separately preincubated in $0.2 \mathrm{M}$ of citrate phosphate buffer at $\mathrm{pH} 4 \& 5$, phosphate buffer at $\mathrm{pH} 6 \& 7$ and Tris- $\mathrm{HCl}$ buffer at 7.6, $8.0,8.5$, \& 9.0 for $1 \mathrm{~h}$ and the residual activities were determined under standard assay conditions. Residual activity in samples without incubation was taken as 100 $\%$. The inactivation rate constants, $\mathrm{K}$ and the half-life time, $t 1 / 2$, were calculated with the following equation:

(Bailey et al., 1986)

Half life $=0.693 /$ slope of the straight line Deactivation rate constant $(K)=$ slope of the straight line

\section{Preparation of hydrogels}

Unless otherwise stated, the poly PVA hydrogel was prepared as follows: $1 \mathrm{gm}$ of PVA (14000 m.w) was dissolved in $10 \mathrm{~mL}$ of bi-distilled water and heated at 90 ${ }^{\circ} \mathrm{C}$ in water bath for $50 \mathrm{~min}$. Then, the prepared (PVA) was grafted with two kinds of monomers, PVP\& HEMA in concentrations of $15 \%, \mathrm{w} / \mathrm{v} \& 0.5 \mathrm{~mL} \mathrm{v} / \mathrm{v}$, respectively. The mixtures were distributed separately into glass test tubes, the nitrogen gas was passed through the solutions for $24 \mathrm{~h}$ to remove the dissolved oxygen. The hydrogels were autoclaved at $121^{\circ} \mathrm{C}$ for $120 \mathrm{~min}$. (Razzak et al., 1999).

Immobilization techniques

\section{Method I:}

The polymers were prepared as described above. Unless otherwise stated, $1 \mathrm{~mL}$ of lipase was mixed with 
previously prepared hydrogels (PVA, PVA/HEMA and PVA/PVP) and homogenized with shaking technique. Then, the mixtures were irradiated to $20 \mathrm{kGy}$ (unless otherwise stated) at $-78{ }^{\circ} \mathrm{C}$ in a $\mathrm{C}^{60}$ Russian type $\mathrm{y}$ irradiator, at a fixed dose rate of $8 \mathrm{kGy} / \mathrm{h}$. The resultant polymer was cut into granules, approximately $2-3 \mathrm{~mm}$ in diameter. The granules of hydrogels were washed several times with $0.2 \mathrm{M}$ sodium phosphate buffer ( $\mathrm{pH} 7.0)$.

\section{Method II}

The polymer was prepared as described above. The mixtures were irradiated to $20 \mathrm{kGy}$ at $-78{ }^{\circ} \mathrm{C}$ in a $\mathrm{C}^{60}$ Russian type $\mathrm{\gamma}$ - irradiator, at a fixed dose rate of $8 \mathrm{kGy} / \mathrm{h}$. The resultant polymer was cut into granules, approximately 2-3 $\mathrm{mm}$ in diameter. The granules of copolymers were washed several times with $0.2 \mathrm{M}$ Tris$\mathrm{HCl}$ buffer $(\mathrm{pH} 7.5)$ the resultant granules were soaked with excess water for $24 \mathrm{~h}$ until fully swollen. The swollen copolymer granules were immersed in $10 \mathrm{~mL}$ of $0.2 \mathrm{M}$ Tris- $\mathrm{HCl}$ buffer $(\mathrm{pH}$ 7.5) containing $1 \mathrm{~mL}$ of lipase suspension for $24 \mathrm{~h}$, then the polymer carrier of immobilized lipase was washed several times with $0.2 \mathrm{M}$ Tris- $\mathrm{HCl}$ buffer ( $\mathrm{pH} 7.5)$.

$$
\text { Immobilization }(\%)=\frac{\text { Activity of immobilized enzyme }}{\text { Activity of free enzyme-Activity of wash }}
$$

\section{Enzyme recycling stability}

The PVA/ HEMA immobilized lipase was filtered after each reaction batch rinsed with $\mathrm{Tris}-\mathrm{HCl}$ buffer and then introduced into the next reaction cycle. The recycling efficiency of immobilized lipase (PVA/HEMA) was explored by measuring the enzyme activity in each successive reaction cycle and expressed by recycling efficiency defined as follow.

$$
\text { Recycling efficiency }=\frac{\text { Enzyme activity in the } \mathrm{n}^{\text {th }} \text { cycle }}{\text { Enzyme activity in the } 1^{\text {st }} \text { cycle }} \times 100
$$

\section{RESULTS AND DISCUSSION}

\section{Partial purification of enzyme}

The lipase was partially purified by ammonium sulphate precipitation (60\% saturation). This saturation was used for further investigations of enzyme immobilization. This saturation achieved a specific enzyme activity of $114.0 \mathrm{U} /$ $\mathrm{mg}$ protein. These results are similar to those obtained by (Xu and Chen, 2006) who used ammonium sulphate in precipitation of Antrodia cinnamomea lipase.

\section{Effect of different copolymer hydrogels on immobilization yield}

The degree of cross linking and swelling of poly PVA was greatly affected by the addition of PVP and HEMA monomers as cross linking agents and this is shown in Table 1 . The immobilization yield $(31.74 \%)$ was attained when the enzyme was entrapped in poly (PVA/HEMA) of composition (9.5: 0.5, v/v). While using poly (PVA/PVP) of composition $(9: 1 \mathrm{v} / \mathrm{v})$ lead to slight decrease in immobilization yield to $15.87 \%$. On the other hand using of poly (PVA) of composition (10\%) alone decreased immobilization yield to $6.35 \%$. The copolymerization of such high hydrophilic polymer (PVA) with hydrophilic glass forming monomer (HEMA) changed the properties of the polymer matrix to be a more suitable porous and swelling gel, this retard the leakage of the enzyme from the hydrogel, In addition, the grafting of PVA with PVP remained the polymer very fragile and with a more porous structure, more water content and then increase the enzyme leakage from the hydrogel. On the contrast, the use of poly (PVA) hydrogel make a polymer matrix had a porous structure of small porosity, then hindrance the interaction between the enzyme and the substrate (Razzak et al.,1999; Darwis et al., 2002; Abd El-Hadi and Abd El-Rehim, 2004)

Table 1: Effect of $y$ - irradiated poly PVA cross linked with different hydrogels on immobilization yield

\begin{tabular}{lc}
\hline Polymer carrier & Immobilization yield (\%) \\
\hline${ }^{*}$ Free enzyme & 0 \\
PVA $(14.000)$ & 6.35 \\
PVA: PVP $(9: 1)$ & 15.87 \\
PVA: HEMA (9.5: $0.5 \%)$ & 31.74 \\
\hline
\end{tabular}

Cross liking behavior of $y$-irradiated doses of poly (PVA, PVA/HEMA \& PVA/PVP) hydrogels on the immobilization yield

Activity of immobilized enzyme was affected by the total absorbed $\mathrm{y}$-irradiation doses of PVA/HEMA and PVA/PVP as previously prepared. Figure 1 investigated the relationship between the immobilized enzyme activity and the degree of cross linking of the previous prepared polymers at $\mathrm{Y}$-rays doses $(10,15,20,25 \mathrm{kGy})$. The maximum immobilization yields $(60.31,55.5 \%)$ were obtained when the enzyme was immobilized by PVA/HEMA \& PVA respectively at $\mathrm{\gamma}$ - dose (15 kGy). On the other hand, immobilization yield $(30.16 \%)$ was obtained when the enzyme immobilized with PVA/PVP at $Y$ - dose (10 kGy). The increase or decrease in the $Y$ irradiation dose $(10,20$ and $25 \mathrm{kGy})$ respectively lead to an obvious decrease in immobilization yield $(28.57,6.35$ \& $0.0 \%$, respectively) in case of enzyme immobilization with PVA and 25.4, 31.75 and $23.81 \%$ in case of enzyme immobilization with PVA/HEMA, respectively. The immobilization of enzyme with PVA/PVP at $(15,20$ and $25 \mathrm{kGy}$ ) decreased the immobilization yield to $15.87,9.52$ and $0.0 \%$, respectively.

Changing the radiation dose produces a pronounced effect on the swelling properties of the polymers. This might be explained as high $\mathrm{y}$-dose produce densely cross linked hydrogels which lead to low swelling values and then decrease the diffusion rate of the enzyme. At lower $y$ dose (10 kGy), the decrease in the enzymatic activity was caused by a decrease in the network density and gel 
contents, thus reduce the quantity of the enzyme trapped in the polymer matrix.

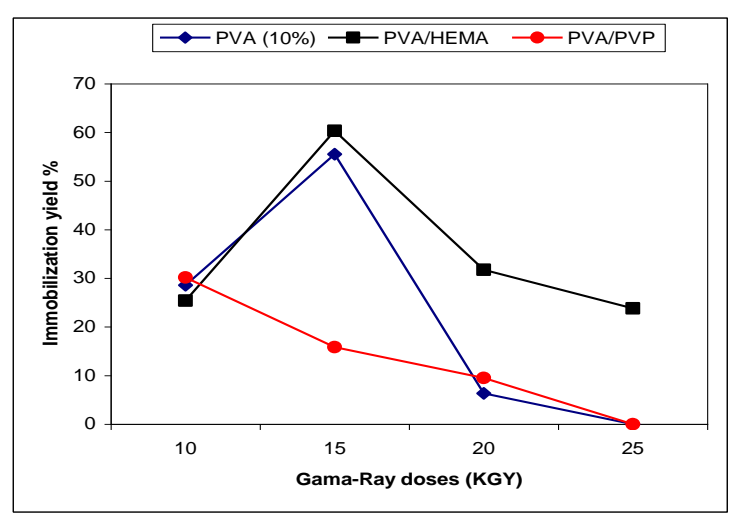

Figure 1: Effect of the degree of cross linking poly (PVA, PVA/HEMA \& PVA/PVP) hydrogels prepared at different $y$-irradiation dose on the immobilization yield

\section{Effect of different HEMA monomer concentrations on immobilization yield}

Effect of different concentrations of HEMA monomer $(0.4$, $0.5,0.6 / \mathrm{mL}$ ) as cross linking agent obtained by $\mathrm{Y}$ irradiation (15 kGy) dose on immobilization yield was investigated and is shown in Figure 2. It is observed that as HEMA concentration increases, the immobilization yield decreases and the maximum immobilization yield (71.43\%) was obtained at $0.4 \mathrm{~mL}$ of HEMA monomer. Increasing HEMA concentration more than $0.4 \mathrm{~mL}$ decreased immobilization yield to (38.1 and $22.22 \%)$ at 0.5 and $0.6 \mathrm{~mL}$, respectively.

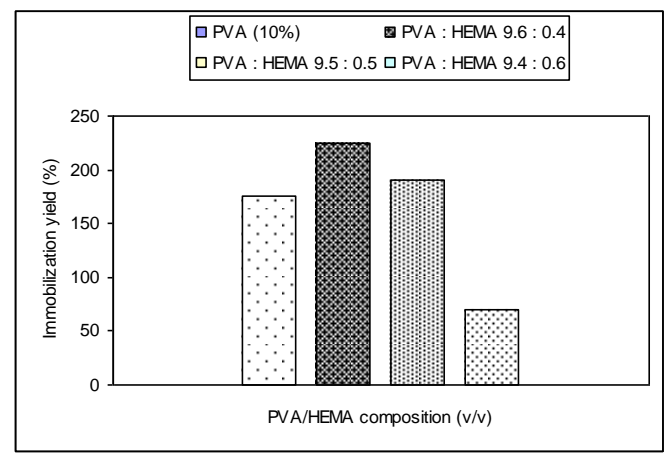

Figure 2: Effect of PVA/HEMA copolymer concentrations $(\mathrm{v} / \mathrm{v})$ at $\mathrm{Y}$-Irradiation dose $15 \mathrm{kGy}$ on immobilization yield

\section{Comparison between methods of immobilization using poly PVA grafted with different concentrations of HEMA monomer}

Different concentrations of HEMA monomer $(0.4 \& 0.5$ $\mathrm{mL} / \mathrm{mL}$ ) as cross linking agent were added to poly (PVA) hydrogel. Two different methods of enzyme immobilization were used; method I involves the incorporation of enzyme within the polymer matrix, while method II involves loading enzyme on the surface polymer matrix (using $\mathrm{y}$-dose of 15 kGy). A result in Table 2 clearly indicates that the maximum immobilization yield $(81.5 \%)$ was obtained by method I using PVA grafted with $0.4 \mathrm{~mL}$ HEMA. Increasing HEMA concentration $0.5 \mathrm{~mL}$ decreased the immobilization yield to $71.43 \%$.

Using method I of immobilization led to slightly decrease in the immobilization yield to $63.5 \%$ \& $60.3 \%$ at concentrations of 0.4 and $0.5 \mathrm{~mL}$ HEMA, respectively. The immobilized enzyme composites obtained at a low concentration $(0.4 \mathrm{~mL})$ of HEMA by method II had a suitable porous structure for the trapping of the enzyme on the surface of the polymer matrix, so that the substrate hydrolyzed easily (Kumakura and Kaetsu, 1982; Zhaoxin and Fujimura, 1993). On the contrast, the trapped enzyme in the polymer matrix decreased the contact action of the enzyme with insoluble substrate and then decreased the immobilization yield (Kumakura \& Kaetsu, 1982).

\section{Biochemical properties of the free and immobilized lipase}

The residual activities for both enzymatic preparations after incubation in the temperature range $30-80{ }^{\circ} \mathrm{C}$ at $\mathrm{pH}$ 7.5 (0.2 M Tris- $\mathrm{HCl}$ buffer) for $15,30 \& 60 \mathrm{~min}-$ are displayed in Fig. 3. Under these conditions, the PVA/HEMA immobilized lipase exhibited higher stability against heat than the free one. The bound enzyme retained $80.5,72.2$ and $55.5 \%$ of its initial activity when incubated at 50,60 and $70{ }^{\circ} \mathrm{C}$, respectively for $15 \mathrm{~min}$. While the free enzyme retained 53.6, 29.3 and $13.58 \%$ of its initial activity at the same temperatures and at the same time. Although the free enzyme was markedly inactivated (no detectable residual activities) at $80{ }^{\circ} \mathrm{C}$ for all times, the immobilized form preserved $(36.11,13.8 \%)$ of its initial activity.

Table 2: Comparison between methods of immobilization using poly PVA grafted with different concentrations of monomer (HEMA)

\begin{tabular}{lll}
\hline $\begin{array}{l}\text { Concentration } \\
\text { of } \\
\text { copolymer (v/v) }\end{array}$ & $\begin{array}{l}\text { Enzyme carrier on the } \\
\text { surface of poly (PVA) } \\
\text { HEMA) }\end{array}$ & $\begin{array}{l}\text { Enzyme } \\
\text { incorporated into the } \\
\text { poly (PVA/HEMA) }\end{array}$ \\
\hline PVA: HEMA & & $\begin{array}{l}\text { Immobilization yield \% } \\
9.6: 0.4\end{array}$ \\
$9.5: 0.5$ & 71.43 & 63.5 \\
\hline
\end{tabular}


This thermal inactivation might be due to the disturbance of globular structure of the protein by heat (Pahujani et al., 2008) or because immobilization provided more rigid external backbone for lipase molecules thus increasing the thermal stability of the immobilized lipase (Nawani et al., 2006). Also, the obtained data confirm the interaction between the support and the enzyme and this improves the enzyme stability (Ogino \& Ishikawa, 2001; Ghamgui et al., 2004). So, inactivation observed with the free enzyme at high temperatures in solution should be considered as a result of lipase denaturation only (Ghamgui et al., 2004). The half life values and thermal inactivation rate constants for the free and immobilized enzymes are presented in Table 3. The higher the temperature, the lower the half life value $t 1 / 2$ and the higher the thermal inactivation rate constant $\mathrm{K}$ for both immobilized and free lipase. However, at the same temperature $\left(50,55,60^{\circ} \mathrm{C}\right)$, the half life values of the immobilized enzyme (5.2, 4.6 and $3.3 \mathrm{~h}$ ) were much higher than those $(3.5,2.6$ and $1.7 \mathrm{~h})$ of the free one.

The calculated deactivation rate constant $\left(2.22 \times 10^{-3}\right.$, $2.5 \times 10^{-3}$ and $3.5 \times 10^{-3}$ ) of the immobilized enzyme at temperatures 50,55 and $60{ }^{\circ} \mathrm{C}$, respectively were lower than those $\left(3.33 \times 10^{-3}, 4.44 \times 10^{-3}\right.$ and $\left.6.66 \times 10^{-3}\right)$ of the free one at the same temperature. These results can be related to the hydrophilic or to the hydrophobic lipase microenvironment (Moreno et al., 1997).

$\mathrm{pH}$ is one of the most important factors influencing not only the side groups of the amino acid dissociations in the protein structure but also the solution chemistry of the insoluble support. Thus, protein support interaction and surface properties of the protein are strongly influenced by the $\mathrm{pH}$ of the solution.

Fig. 4 shows that the immobilized enzyme should high activity compared to the free one at $\mathrm{pH}$ range (4-9), probably due to diffusional limitations of the immobilized enzyme molecules (Ortega et al., 2009). The immobilized Mucor racemosus lipase was markedly stable at $\mathrm{pH} 5.0$ \& 6.0 using citrate-phosphate and phosphate buffer, respectively with optimum $\mathrm{pH}$ 6.0. The free enzyme was inactivated at acidic and alkaline $\mathrm{pH}$. Similar the same results were obtained by the free and immobilized enzyme at alkaline $\mathrm{pH}(8-9)$.

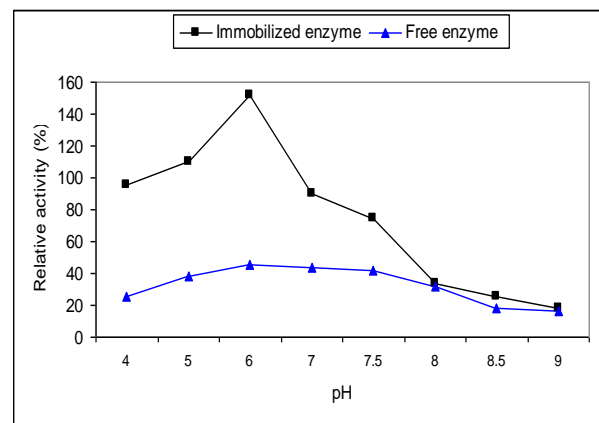

Figure 4: Effect of pH stability on free and immobilized Mucor racemosus lipase
Table 3: Half lives $\left(t_{1 / 2}\right)$ and deactivation rate constant $(\mathrm{K})$ of the free and immobilized Mucor racemosus lipase at three different temperatures

\begin{tabular}{cllll}
\hline & \multicolumn{2}{c}{ Free lipase } & \multicolumn{2}{c}{ Immobilized lipase } \\
\cline { 2 - 5 } $\begin{array}{c}\text { Temperature } \\
\left({ }^{\circ} \mathrm{C}\right)\end{array}$ & $\begin{array}{l}\mathrm{t}_{1 / 2} \\
(\min )\end{array}$ & $\begin{array}{l}\mathrm{K} \\
\left(\mathrm{min}^{-1}\right)\end{array}$ & $\mathrm{t}_{1 / 2}(\mathrm{~min})$ & $\begin{array}{l}\mathrm{K} \\
\left(\mathrm{min}^{-1}\right)\end{array}$ \\
\hline 50 & $3.33 \times 10^{-3}$ & 208.1 & $2.22 \times 10^{-3}$ & 312 \\
55 & $4.44 \times 10^{-3}$ & 156.08 & $2.5 \times 10^{-3}$ & 277.2 \\
60 & $6.66 \times 10^{-3}$ & 104.05 & $3.5 \times 10^{-3}$ & 198 \\
\hline
\end{tabular}

\section{Variation of enzyme activity with repeated batch enzyme reaction}

This effect of buffer was also described by Perrin and Dempesy (1974) who suggested that buffer composition can affect enzyme activity in different ways: ionic strength, interaction with enzyme conformation or active site and interaction with substrate. The recycling efficiency of immobilized (PVA/ HEMA) lipase was presented in Figure 5. The recycling efficiency showed a decrease of $23.1 \%$ after the first batch and lost of its activity after five cycles. The activity decay during recycling may result from enzyme loss due to washing (Hsieh et al., 2009).
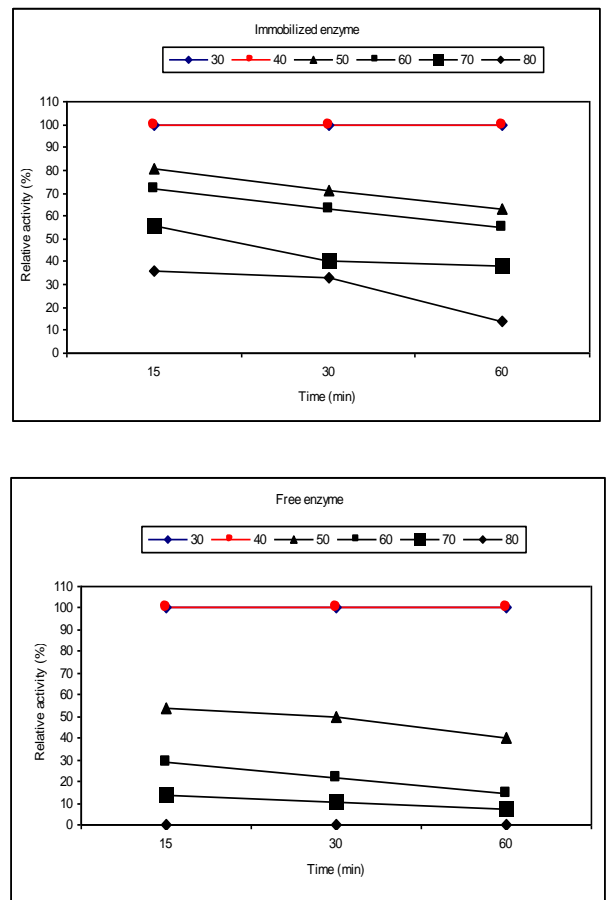

Figure 3: Thermal stability of free and immobilize Mucor racemosus lipase 


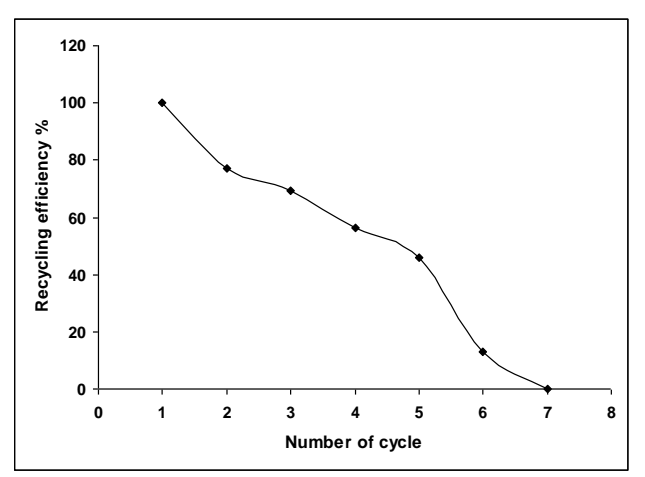

Figure 5: Operational stability of immobilized Mucor racemosus lipase

\section{Conclusion}

We have shown that Mucor racemosus NRRL3631 lipase immobilized in poly (PVA) cross linked with HEMA monomer at $15 \mathrm{kGy}$ electron beam irradiation in order to improve its immobilization yield. In addition, adsorptions of lipase of the surface of poly (PVA/HEMA) lead to an increase in its immobilization yield to $(81.5 \%)$. The immobilized enzyme exhibited a higher stability at different $\mathrm{pH}(4-9)$ and temperature $(30-80)$ than that of the free one. The half life values of the immobilized and free enzymes at $60{ }^{\circ} \mathrm{C}$ were $3.3 \mathrm{~h}$ and $1.73 \mathrm{~h}$, respectively. The immobilized enzyme retained $69.2 \%$ of its initial activity after three cycles. The recycling efficiency of the immobilized PVA/HEMA lipase was decreased by $23.1 \%$ after the first use and reused five cycles. However, immobilization causes structural changes of enzymes, the activity of the immobilized enzymes is generally lower than that of the free one. Moreover, despite the increase in their stabilities, immobilized enzymes are gradually inactivated. Therefore, it is desirable that enzymes are immobilized without loss of activity and they maintain their activities for longer period.

\section{REFERENCES}

Abbas, H., Hiol, A., Deyris, V. and Comeou, L. (2002). Isolation and characterization of an extracellular lipase from Mucor sp. strain isolated from palm fruit. Enzyme and Microbial Technology. 31, 968-975.

Abd El-Hadi, A. (2003). Production of prednisolone by Bacillus pumilus E 601 cells incorporated in radiation induced poly (vinyl alcohol) g-2 hydroxy ethyl meth acrylate cryogels. Process Biochemistry. 38, 16531657.

Abd El-Hadi, A. and Abd El-Rehim, H. A. (2004). Production of prednisolone by Pseudomonas oleovorans cells incorporated into PVP/PEO radiation crosslinked hydrogels. Biomedicine Biotechnology. 4, 219-226.

Akhtar, M. W., Mirza, A. Q. and Chughtai, M. I. D. (1980). Lipase induction in Mucor hiemalis. Applied Environmental Microbiology. 40(2), 257-263.
Bagi, K. Simon, L. M. and Szajani, B.(1997). Immobilization and characterization of porcin pancreas lipase. Enzyme and Microbial Technology. 20, 531-535.

Bailey, J. E. and Ollis, D. F. (1986). Biochemical engineering fundamentals. $2^{\text {nd }}$ edn. Mc Graw-Hill Book Company, United States of America.

Brinbaum, S. (1994). Immobilized enzymes and cells in biochemical reaction. In: Immobilized Biosystems: Theory and Practical Application. Veliky, I. A. and Mclean, R.J. C. (eds.). Blackie Academic and Professional, USA.

Cho, S. W. and Rhee, J. S. (1993). Immobilization of lipase for effective interesterification of fats and oils in organic solvent. Biotechnology Bioengineering. 41, 204-210.

Darwis, D., Stascia, P., Razzak, M. T. and Rosiak, J. M. (2002). Characterization of poly (vinyl alcohol) hydrogel for prosthetic intervertebral disc nucleus. Radiation Physics and Chemistry 63, 539-542.

Fokina. V. V., Arinbasarava. A., Zuborl. A., Lozinsky V. L., Koshcheenkok, A. (1995). Dehydrogenation of steroid substrates by the cells of Arthrobacter globiform is 193 incorporated in poly (vinyl alcohol) cryogels. Applied Biochemistry and Microbiology. 1, 184-189.

Ghamgui, H., Chabauni, K. M. and Gargouri, Y. (2004). 1-butyle oleate synthesis by immobilized lipase from Rhizopus oryzae: A Comparative Study Between nhexane and solvent-free system. Enzyme and Microbial Technology. 35, 355-363.

Giuliano, M., Schiralic, Maresca, C., Esposito, V. and De R. M. (2003). Immoblized Proteus mirabilis in poly (Vinyl alcohol) cryogels for L(-)carnitine production. Enzyme and Microbial Technology. 32, 507-512.

Higa, O. Z., del Mastro, N. L., Castagnet, A. C. (1986). Immobilization of cellulose and cellobiose by radiation-induced polymerization. Radiatiation Physics and Chemistry. 27(4), 311 -316.

Hsieh, H., Kuan, I., Lee, S., Tien, G., Wang, Y., Yu, C. (2009). Stabilization of $D$-amino acid oxidase from Rhodosporium toruloides by immobilization onto magnetic nanoparticles. Biotechnology Letter. 31, 557-563.

Inagaki, M., Hiratake, J., Nishioka, I. and Oda, J. (1991). Lipase- catalyzed kinetic resolution with in situ racemisation: One pot synthesis of optically active cyanohydrin acetates. Journal of American Chemists Society. 113, 9360-9361.

Kanwar, L. and Goswami, P. (2002). Isolation of a Pseudomonas lipase produced in pure hydrocarbon substrate and its application in the synthesis of isoamyl acetate using membrane immobilized lipase. Enzyme and Microbial Technology. 31, 727-735.

Kilbanov, A. M. (1990). Asymetric transformation catalyzed by enzymes in organic synthesis. Accounts of Chemical Research 23, 114-120.

Kumakura, M. and Kaesru, I. (1982). Effect of polymer matrix on the immobilization of lipase by radiation polymerization. Polymer Bulletin. 8, 75-79. 
Lowry, O. H. Rosenbro, N. J.; Farr, A. L. and Ranadall, R. J. (1951). Protein measurement with the folin Phenol reagent . Journal of Biological Chemistry. 193, 265-276.

Lozinsky, V. I., Zubov, A. L., Titova, E. F. (1997). Poly (vinyl alcohol) cryogens employed as matrices for cell immobilization. 2. Entrapped cells resemble porous fillers in their effects on the properties of PVACryogel carrier. Enzyme and Microbial Technology. 20, 182-190.

Malcata, F. X., Reyes, H. R., Garcia, S. G., Hill, C. G. and Amudson, C. H. (1990). Immobilized lipase reactors for modification of fats and Oils. A review. Journal of American Oil Chemists' Society. 67, 890 . 910.

Moreno, J. M., Arroyo, M., Hernaiz, M. J. and Sinisterra, J. V. (1997). Covalent immobilization of a pure isoenzyme from a lipase from Candida rugosa. Enzyme and Microbial Technology. 27, 552-558.

Nawani, N., Singh, R. and Kaur, J. (2006). Immobilization and stability studies of a lipase from thermophilic Bacillus sp.: The effect of process parameters on immobilization of enzyme. Electronic Journal of Biotechnology. 9(5), 559-565.

Norin, M., Boutelje, J., Holmberg. E. and Hult, K. (1988). Lipase immobilized by adsorption. Effect of support hydrophobicity on the reaction rate of ester synthesis in cyclohexane. Applied. Microbiology and Biotechnology. 28, 527-530.

Ogino, H. and Ishikawa, H. (2001). Enzymes which are stable in the presence of organic solvents. Journal of Bioscience and Bioengineering. 91, 109-116.

Ortega, N., Mateos, M. P., Pilar, M. C. and Busto, M. D. (2009). Nutrase immobilization on alginateglutraldehyde beads by covalevt attachment. Journal of Agriculture Food Chemistry. 57, 109-115.

Pahujani, S., Kanwar, S. S., Chauhan, G. and Gupta, R. (2008). Glutaraldehyde activation of polymer Nylon-6 for lipase immobilization: Enzyme characteristics and stability. Bioresource and Technology. 99, 25662570.

Perrin, D. D., Dempsey, B. (1974). Buffers for $\mathrm{pH}$ and metal ion control. Chapman and Hall, London, U. K.

Pizarro, C., Fernandez-Torroba, M. A., Benito, C. and Gonzalez, J. M. (1997). Optimization by experimental design of polyacrylamide gel composition as support for enzyme immobilization by entrapment. Bioengineering. 53(5), 497-506.

Razzak, M. T., Zainuddin, E., Dewi, S. P., Lely, H., Taty, E. and Sukirno, Z. (1999). The characterization of dressing component materials and radiation formation of PVA-PVP hydrogel. Radiation Physics and Chemistry. 55, 153-165.

Roberts, S. M. and Turner, N. J. (1992). Some recent developments in the use of enzyme-Catalyzed reaction in organic synthesis. Journal of Biotechnology. 22, 227-244.

Starr, M. P. (1941). Spirit blue agar. A medium for the detection of lipolytic microrrganisms. Science. 93, 333.
Vaidya, B. K. and Singhal, R. S. (2008). Use of insoluble yeast $\beta$-glucan as a support for immobilization of Candida rugosa lipase. Biointerfaces. 61(1), 101-105.

$\mathrm{Xu}$, C. J. and Chen, G. (2006). Purification and Partial characterization of a lipase from Antodia cinamomea. Process Biochemistry. 41, 734-738.

Zhaoxin, L. and Fujimura, T. A. (1993). Study on ethanol production of yeast cells immobilized with polymer carrier produced by radiation polymerization. Radiation Physics and Chemistry. 42(4-6), 923-929. 